\title{
Physics Teachers' Perspectives on The Availability of The Integration of E-Formative Assessment in E-Learning based on Website (EFA in ELboW) during Covid-19 Pandemic
}

\section{Utoro Romadhon ${ }^{1}$, Sukarmin ${ }^{2}$, Sri Budiawanti ${ }^{3}$}

1,2,3 Master of Physics Education, Sebelas Maret University Surakarta, Surakarta, Indonesia

A R T I C L E I N F O

Article history:

Received 02 December 2020

Received in revised

Form 06 January 2021

Accepted 30 January 2021

Available online 01

February 2021

Keywords:

E-Formative, E-learning,

Physics Learning Process

\section{A B S T R A C T}

In the field of education, the COVID-19 demands changes in the learning process. It is important to know the changes that have occurred so that we can take some actions to face the changes that occurred, and help teachers prepare for the changes that occur in the learning process, especially in the physics learning process. This study aims to determine changes in the teaching, assessing, and using validated instrument aspect due to the COVID-19 pandemic. Also, gathered teacher perspectives on the availability of $E$ Formative Assessment in Web-based E-Learning (EFA on ElboW) integration. The sampling technique used in this study was quota sampling. Data were collected from 33 physics teachers from various districts in Indonesia and analyzed using quantitative descriptive. As a result, the significant value of paired sample test for teaching, assessing and using validated instrument aspect before and during COVID-19 successively are $0.000,0.003$, and 0.183 . Then all respondents agreed that the Integration of E-Formative Assessment in Website-Based E-Learning (EFA in ELboW) was needed by physics teachers during the COVID-19 Pandemic. It can be concluded that there are changes in the teaching and assessing aspect. Also, the Integration of E-Formative Assessment in Website-Based E-Learning (EFA in ELboW) was needed by physics teachers to prepare them to deal with the changes that occur in learning due to the COVID-19 Pandemic. Of course, this article has great implication for teachers and researchers.

\section{Introduction}

Severe Acute Respiratory Syndrome coronavirus 2 (SARS-CoV-2) was first found and confirmed in December 2019 in Wuhan, China (Yuliana, 2020) (Li, et al., 2020). This virus spread easily, and quickly, also can cause death in an infected person (Zheng, 2020). In Indonesia until now, more than 4700 people have died. The percentage of people recovered is more than those who died. On July 25, 2020, The Case Fatal Rate Indonesia is about 4,7\% (Infeksi Emerging, 2020). It is a pathetic reality because it has a tremendous impact on all sectors. In the economy, most of the people experienced in revenue declines, a lot of companies deactivate their employer and Other. In Indonesia, the household sector is the most economic sector impacted by the COVID-19 pandemic (Susilawati, Falefi, \& Purwoko, 2020).

Not only the economy but also education is also affected. In the education sector, there is the term learning. The learning is the activity of someone who appears in the form of sitting in class, listening to the teacher who is explaining, memorizing something, or rework what he had obtained at school (Rusyan, Kusdinar, \& Arifin, 1989). Learning is a human characteristic that distinguishes humans from other creatures. More specifically, the learning means a process carried out by individuals to get a new behavior change either in whole or only in part, as a result of the individual's own experience in interaction with his environment. Learning in this activity is an activity to process the information received. Learning is an activity carried out intentionally and consciously. Before COVID-19, the learning process os carried out face-to-fave in schools. But now, learning process is conducted by distance learning. Distance learning is a policy taken by the government to reduce the level of the spread of the Coronavirus (Wargadinata, Maimunah, Dewi, \& Rofiq, 2020). Distance learning has the principle of communication between students and their tutors from a certain distance. It can be more effective when we utilize e-learning as the learning media (Tavukcu, Arap, \& Özcan, 2011). Synchronous and Asynchronous are two methods to implement distance learning (Tavukcu, Arap, \& Özcan, 2011). Synchronization has several characteristics, namely: live, scheduled, learning-oriented interactions, facilitate instruction, and real-time (Shahabadi \& Uplane, 2015). Asynchronous learning is independent and possible participants to engage in the exchange of ideas 
or information without depending on the involvement of other participants. There are some advantages of distance learning, namely; Can be conducted anywhere and anytime, more economical, more time saving, no commuting, flexibility in choosing course/class (for some education institution), for those who work and want to improve their qualifications, distance learning is anappropriate solution. it makes learning process becomes affordable, and Personalized (Sadeghi, 2019) (Sandybayev, 2020).

In learning there is an important part that cannot be separated, namely "assessment". Hill in journal (Jingga, Mardiyana, \& Triyanto, 2018) as saying "the role of classroom assessment is to improve students 'learning and teachers' teaching to ensure that students reach their individual potential". Assessment is used to find out what someone knows, and what can be done, and decisions based on what has been learned (Baird, Andrich, Hopfenbeck, \& Stobart, 2017). By using assessment, educators can find out the abilities of students, learning methods, and the success of students (Alfian, Aminah, \& Sarwanto, 2015). As stated before, Assessment and learning are a unity so this allows aspects of assessment to also be affected by the COVID-19 pandemic.

As the learning process is affected by a pandemic, it is likely that there will be changes occurring there. Changes that occur in the learning process if not scientifically studied and not informed to education practitioners will result in the unpreparedness of education practitioners so that the learning process does not go well and it is feared that it will affect the quality of students. Therefore, this study will identify the changes that occur in the physics learning process, both in the description and in quantitative to know how the COVID-19 pandemic affected the education field. Based on the article (Upoalkpajor \& Upoalkpajor, 2020), the researchers conducted research in 2020 with the number of research participants is about 133. The result of the research is interesting; it concludes that the Covid-19 pandemic has an impact on the education sector in Ghana. Furthermore, the research in the article (Jadhav, Bagul, \& Aswale, 2020) is interesting and resulted in the same conclusions as to the ulpakajor's research.

This study aims to determine changes in the teaching, assessing, and using validated instrument aspect due to the COVID-19 pandemic. Also, gathered teacher perspectives on the availability of EFormative Assessment in Web-based E-Learning (EFA on ElboW) integration.

\section{Methods}

The participants were chosen by quota sampling method. The quota sampling method is a nonrandom sampling technique in which participants are selected based on specific characteristics that have been determined by the researcher so that the number of samples will match with the distribution of characteristics of the larger population (Taherdoost, 2016). The participants of this research were 33 teachers from different regencies in Indonesia, namely: Bandar lampung, Banyumas, Boyolali, Grobogan, Jayapura, Jepara, Karanganyar, Kartasura, Toli-toli, Wonogiri, Yogyakarta, Klaten. Pati, Lampung Barat, Oki, Pandeglang, Sragen, Tanggamus, and Ngawi. There were 23 female and 10 male teachers who participated in this research. The specific subject characteristic is teachers who have teaching experience before and during the COVID-19 pandemic so that the teacher can fill out a questionnaire according to their teaching experience and the data that will be obtained is data that is in accordance with reality.

A Questionnaire was used by researchers to gather data on the teachers' perspectives on the availability of integration of the E- Formative Assessment in E-Learning based on the Website (EFA in ElboW) during the COVID-19 pandemic. The Questionnaire was validated by two senior lecturers of Magister Physics Education of Sebelas Maret University, and it was constructed as a Likert-type rating scale and composed of 62 Likert type questions, on a four-point range. Data collection was carried out during the COVID-19 pandemic, to be more precise on 2 July-6 July 2020. Due to COVID-19 which requires humans to do physical distancing because it leads the overall cases to decrease (Prem, et al., 2020), the questionnaire was given to the teacher by the researcher via a link. The gathered data were analyzed using descriptive and quantitative methods. Various quantitative methods are used, including the normality test, homogeneity test, and t-test. The software used to analyze the data were Microsoft Excel, and SPSS (Statistical Package for the Social Sciences)..

\section{Result and Discussion}

\section{Assessing Aspect}

In this aspect, the researchers investigate: (1) the teacher's experience in conducting assessments at the beginning and end of physics learning, (2) the teacher's experience in giving assignments, and (3) the teacher's experience in providing feedback on assignments and student test results before the COVID19 occurred, and during the COVID-19 pandemic occurred. 
At the beginning of the physics learning process, a teacher has to assess the students' capabilities. The teacher is assessing students' capabilities at the beginning of the physics learning process helps teachers plan to recognize the strengths, weaknesses, and personalities of each student. The distribution of the teachers' experience doing assessments at the beginning of physics learning before and during the COVID-19 pandemic shown in Table 1.

Table 1. Teachers' Experience Doing Assessments at The Beginning of Physics Learning Process

\begin{tabular}{lccc}
\hline & & \multicolumn{2}{c}{ Condition } \\
\cline { 3 - 4 } & & Before & During \\
\hline EAB* & Never & 0 & 7 \\
& Rare & 6 & 15 \\
& Often & 20 & 11 \\
& Always & 7 & 0 \\
\hline
\end{tabular}

Table 1 shows the change of teachers in conducting assessments at the beginning of the physics learning process due to the COVID-19 pandemic. Before the COVID-19, there were no teachers who did not assess at the beginning of physics learning, or all teachers assessed at the beginning of physics learning before the COVID-19 pandemic occurred. However, during the COVID-19, there are 7 teachers or $21 \%$ who assessed at the beginning of the physics learning process.

Because there is a significant change in the experience of teachers in conducting assessments at the beginning of physics learning, the researchers enthusiastically investigated the forms of assessment at the beginning of physics learning used by teachers before and during the COVID-19 pandemic. Before the COVID-19 pandemic, $100 \%$ of the teachers had used the essay (test), $96.9 \%$ of the teachers had used the multiple-choice (test), 87.88\% had used the observation assessment, $63.64 \%$ had used the questionnaire, $87.88 \%$ had used portfolio assessment form, and $75.7 \%$ of teachers had used other forms/types of assessment.

During the pandemic, $81.82 \%$ of the teachers had used the essay assessment (test), $69.70 \%$ of the teachers had used the multiple-choice assessment form (test), 60.6\% had used the observation assessment form, $45.45 \%$ had used the questionnaire assessment form, $57.5 \%$ have used a portfolio assessment, and $33.33 \%$ of teachers have used another form of assessment. Data shows that there is a reduction in using various forms/types of assessment at the beginning of learning. Descriptively, It indicates that there is a change in teachers' experience doing an assessment at the beginning of the physics learning process because of the COVID-19.

The frequency distribution of the teacher's experience doing assessments at the end of learning before and during the COVID- 19 pandemic in Table 2.

Table 2. Assessing Experiences at The End of Physics Learning Process

\begin{tabular}{cccc}
\hline & & \multicolumn{2}{c}{ Condition } \\
\cline { 3 - 4 } & & Before & During \\
\hline \multirow{2}{*}{ EAE* $^{*}$} & Never & 0 & 1 \\
& Rare & 3 & 10 \\
& Often & 16 & 14 \\
& Always & 14 & 8 \\
\hline
\end{tabular}

*Experience of Assessing at the End of Physics learning process

Table 2 shows the change in teachers' experience in conducting an assessment at the end of physics learning due to the Covid-19 pandemic. Table 2 shows that there were no frequencies of teachers who did not assess at the end of physics learning or all teachers had assessed at the end of physics learning before the Covid-19 pandemic occurred. During the Covid-19 pandemic, there is 1 teacher or 3\% of teachers who do not assess at the end of the physics learning process. Also, the change in the frequency of teachers who always had assessed at the end of learning is quite significant.

Because there is a change in assessing at the end of the physics learning process, the researchers enthusiastic to investigate the forms of assessment at the end of the physics learning process that used by teachers' assessment at the end of physics learning that used by teachers before and during the COVID-19 pandemic. Before the COVID-19 pandemic, $100 \%$ of the teachers had used the essay assessment form (test), 96.9\% of the teachers had used the multiple-choice assessment form (test), 90.91\% had used the 
observation assessment form, $66.7 \%$ had used the questionnaire assessment form, $87.88 \%$ used the form of portfolio assessment, and $57.58 \%$ of teachers used another form of assessment.

During the COVID-19 pandemic, 93.94\% of teachers had used essay assessment forms (test), 93.94\% of teachers had used multiple-choice assessment forms (test), $63.64 \%$ had used observation assessments, $48.48 \%$ had used questionnaire assessment form, $66.67 \%$ had used a portfolio assessment form, and $45.45 \%$ of teachers have used other forms of assessment. Data shows that there is a reduction in inexperience in using the various assessment form at the end of physics learning. It indicates a change in teachers' experience in assessing at the end of physics learning due to the existence of the COVID-19 pandemic.

Table 3. The Frequency Distribution of Teachers' Experience on Giving Assignment, Assignment, and Test Result Feedback.

\begin{tabular}{cccccccc}
\hline & & \multicolumn{2}{c}{ EoGA* $^{*}$} & \multicolumn{2}{c}{ EoGAF** } & \multicolumn{2}{c}{ EoGTRF*** } \\
\cline { 2 - 8 } & & Never & Ever & Never & Ever & Never & Ever \\
\hline \multirow{2}{*}{ Condition } & Before & 1 & 32 & 1 & 32 & 0 & 33 \\
& During & 2 & 31 & 2 & 31 & 3 & 30 \\
\hline
\end{tabular}

Experience on Giving Assignment*

Before the COVID-19 pandemic, there is 1 teacher who had never given an assignment, but during COVID-19, a teacher who had never given assignments became 2 teachers, and so was the provision of feedback on students' assignments. For feedback on test results before the COVID-19 pandemic, all teachers provide feedback on student test results. However, during the COVID-19 pandemic, teachers who gave feedback on student test results were reduced to 30 teachers. It shows the differences between assignment, assignment feedback, and test results before and during COVID-19.

However, the purpose of using descriptive methods is only to know the description of the data only, not to decide about the difference between how the teacher's experience assesses in the learning process before and during the COVID-19 pandemic. The data is analyzed using a t-test to assume the difference between both. Before conducting the $t$-test, the analysis prerequisite test is a test of normality and homogeneity.

Table 4. Normality Test of Assessment Aspects of Physics Learning Process Before-During Pandemic COVID-19

\begin{tabular}{cccc}
\hline & \multicolumn{3}{c}{ Shapiro-Wilk } \\
\cline { 2 - 4 } & Statistic & Df & Sig. \\
\hline ABC19* & 0,970 & 33 & 0,489 \\
ADC19** $^{*}$ & 0,973 & 33 & 0,573 \\
\hline
\end{tabular}

Assessment Aspect on Physics Learning Process Before COVID-19 Pandemic*

Assessment Aspect on Physics Learning Process During COVID-19 Pandemic**

To decide whether the data follow the normal distribution, We can see it throughout the significant value. If the significance value of the data is larger than the alpha 0.05 , the data follows a normal distribution. The significance value of the data aspects of how the teacher assessed before and during COVID-19 are 0.489 and 0.573 respectively so that this data follows the normal distribution then a homogeneity test can be conducted.

Table 5. Homogeneity Test of Assessment Aspects of Physics Learning Process Before-During COVID-19 pandemic

\begin{tabular}{lcccc}
\hline & \multicolumn{5}{c}{ Levene test } \\
\cline { 2 - 5 } & Levene Statistic & df1 & df2 & Sig. \\
\hline ABC19-ADC19 & 3.589 & 1 & 64 & 0.063 \\
\hline
\end{tabular}

Based on Table 5, it is evident that the significant value of the two data is more than 0.05 . Therefore, both data are homogeneous. Because all the analysis prerequisites are qualified, then a t-test is performed. 
Table 6. Paired Samples Test

\begin{tabular}{llll}
\hline & \multicolumn{3}{l}{ Paired Samples Test } \\
\hline ABC19 - ADC19 & $\mathrm{t}$ & $\mathrm{df}$ & Sig. (2-tailed) \\
\hline
\end{tabular}

The significant value in table 8 is 0.000 . Then the significant value is less than 0.05 , the decision is the data has a significant difference, vice versa. It shows that there is a significant difference between assessments in physics learning before and during the COVID-19 pandemic.

\section{Teaching Aspect}

In this aspect the researcher investigated, (1) the experience of the teacher in conducting online learning, (2) the experience of the teacher carrying out the discussion, and (3) the experience of the teacher in carrying out laboratory practice before and during the COVID-19 pandemic occurred. The distribution of the teacher's experience doing online physics learning, conducting discussions, and carrying out physics laboratory practice before and during the COVID-19 pandemic shown in Table 7.

Table 7. Frequency Distribution of Teachers' Experience Carrying Out Online Learning, Discussions, and Laboratory Practice Before and During The COVID-19 Pandemic

\begin{tabular}{lccccccc}
\hline & & \multicolumn{2}{c}{ OLE* $^{*}$} & \multicolumn{2}{c}{ DE** $^{* *}$} & \multicolumn{2}{c}{ LPE*** $^{* *}$} \\
\cline { 2 - 7 } & & Never & Ever & Never & Ever & Never & Ever \\
\hline \multirow{2}{*}{ Condition } & Before & 4 & 29 & 0 & 33 & 0 & 33 \\
& During & 1 & 32 & 4 & 29 & 18 & 15 \\
\hline
\end{tabular}

Online Learning Experience*

Discussion Experience**

Laboratory Practice Experience***

Table 7 shows the distribution of teacher experiences in learning physics online, discussion, and physics laboratory practice. Before the COVID-19 pandemic, teachers who had never studied physics online were $12.12 \%$, but during the COVID-19, it changed to $3 \%$. The frequency distribution of teachers doing online learning is in Table 8.

Table 8. The Frequency Distribution of Teachers Doing Online Learning

\begin{tabular}{cccc}
\hline & OLE & Before Covid-19 Pandemic & During Covid-19 Pandemic \\
\hline \multirow{4}{*}{ Freq } & Never & 4 & 1 \\
& rare & 15 & 6 \\
& often & 8 & 17 \\
& Always & 6 & 9 \\
& Total & 33 & 33 \\
\hline
\end{tabular}

Then all teachers always carry out discussions before COVID-19. Because of the COVID-19 pandemic, there are $12.12 \%$ of teachers who did not have to discuss during online physics learning. The frequency distribution of teachers conducting discussions before and during COVID-19 is in Table 9.

Table 9. The Frequency Distribution of Teachers Doing Discussion in Online Learning

\begin{tabular}{cccc}
\hline \multicolumn{2}{c}{ DE } & Before Covid-19 Pandemic & During Covid-19 Pandemic \\
\hline \multirow{4}{*}{ Freq } & Never & 0 & 4 \\
& Rare & 2 & 13 \\
& Often & 25 & 16 \\
& Always & 6 & 0 \\
\cline { 2 - 4 } & Total & 33 & 33 \\
\hline
\end{tabular}

The researchers investigate the teachers' experience change in conducting discussion before and during the COVID-19 pandemic. Before COVID-19, the score of the teacher in conducting discussion is 
about 78. But During COVID-19, it becomes 59. Of course, it shows a significant difference is about 78. But During Covid-19, it becomes 59. Of course, it shows a significant difference.

In connection with the laboratory practice, all teachers have involved students in the laboratory practice. However, during the pandemic, there were $54.54 \%$ of teachers did not incorporate students in experimental activities. The frequency distribution of teachers who conducted laboratory practice in physics learning before and during COVID-19 is in Table 10.

Table 10. The Frequency Distribution of Teachers Who Conducted Laboratory Practice in Physics Learning Before and During COVID- 19.

\begin{tabular}{cccc}
\hline & LPE & Before Covid-19 Pandemic & During Covid-19 Pandemic \\
\hline \multirow{4}{*}{ Freq } & Never & 0 & 18 \\
& rare & 20 & 10 \\
& often & 12 & 5 \\
& Always & 1 & 0 \\
& Total & 33 & 33 \\
\hline & Total & 33 & 33 \\
\hline
\end{tabular}

There are indications that there are differences between aspects of teaching physics before and during the COVID-19. However, the purpose of using descriptive methods is only to know the description of the data only, not to decide about the difference between how the teacher's experience assesses in the learning process before and during the COVID-19 pandemic. The data is analyzed using a t-test to assume the difference between both. Before conducting the t-test, the analysis prerequisite test is a test of normality and homogeneity.

Table 11. Normality Test of Teaching Aspects of Physics Learning

\begin{tabular}{cccc}
\hline & \multicolumn{3}{c}{ Shapiro-Wilk } \\
\cline { 2 - 4 } & Statistic & df & Sig. \\
\hline ABC19* & 0,996 & 33 & 0,008 \\
ADC19** & 0,953 & 33 & 0,165 \\
\hline
\end{tabular}

Assessment Aspect on Physics Learning Process Before Pandemic Covid-19*

Assessment Aspect on Physics Learning Process During Pandemic Covid-19**

According to Table 11, the assessment of physics learning before the COVID-19 pandemic does not follow the normal distribution, to test whether data has differences between both, the researchers used the Wilcoxon method.

Table 12. T-test using Wilcoxon Method

\begin{tabular}{cc}
\hline & Paired Sample Test \\
\hline & Sig. (2-tailed) \\
\hline ABC19 - AAC19 & 0.003 \\
\hline
\end{tabular}

The significant value in table 15 is 0.003 . When the significant value is less than 0.05 , the decision is the data has a significant difference, vice versa. It shows that there is a significant difference between the teaching in physics learning before and during the COVID-19 pandemic. The distribution of teacher experience using physic assessment instruments that have been validated before and during the COVID19 pandemic are shown in Table 13.

Table 13. The changes in teacher experience in using physic Validated assessment instruments before and during the COVID-19 pandemic.

\begin{tabular}{cccc}
\hline \multicolumn{2}{c}{ UVI } & Before Covid-19 Pandemic & During Covid-19 Pandemic \\
\hline \multirow{4}{*}{ Freq } & Never & 1 & 3 \\
& Rare & 13 & 14 \\
& Often & 18 & 15 \\
& Always & 1 & 1 \\
\cline { 2 - 4 } & Total & $\mathbf{3 3}$ & $\mathbf{3 3}$ \\
\hline
\end{tabular}


Before COVID-19, Score of websites, journals, books, and self- made instruments as sources of assessment instruments in the sequence are 50.75, 46.31, 70.45, and 75.75. During COVID-19, Score of websites, journals, books, and self-made instruments as sources of assessment instruments in the sequence are 59, 46.96, 68.18, and 69.69. Based on descriptive analyze, there are only slight changes in teacher experience using physic assessment instruments from various sources before and during the COVID-19 pandemic. However, the purpose of using descriptive methods is only to know the description of the data only, not to conclude about the difference between how the teacher's experience assesses in the learning process before and during the COVID-19 pandemic. The data is analyzed using a t-test to assume the difference between both. Before conducting the t-test, the analysis prerequisite test is a test of normality and homogeneity.

Tabel 14. Normality Test of Using Instrument Aspects of Physics Learning Process Before-During Pandemic COVID-19

\begin{tabular}{cccc}
\hline & \multicolumn{3}{c}{ Shapiro-Wilk } \\
\cline { 2 - 4 } & Statistic & Df & Sig. \\
\hline UIBC19* & 0.960 & 33 & 0.257 \\
UIDC19** & 0.946 & 33 & 0.105 \\
\hline
\end{tabular}

Using Instrument Aspect on Physics Learning Process Before Pandemic Covid-19*

Using Instrument Aspect on Physics Learning Process During Pandemic Covid-19**

To decide whether the data follow the normal distribution, we can see it throughout the significant value. If the significance value of the data is larger than the alpha 0.05 , the data follows a normal distribution. The significance value of the data aspects of using assessment instrument before and during COVID-19 are 0.257 and 0.105 respectively so that this data follows the normal distribution then a homogeneity test can be conducted.

Tabel 15. Homogeneity Test of Using Assessment Instrument in Physics Learning Process Before-During Covid-19 pandemic

\begin{tabular}{ccccc}
\hline & \multicolumn{4}{c}{ Levene test } \\
\cline { 2 - 5 } & Levene Statistic & df1 & df2 & Sig. \\
\hline UIBC19-UIDC19 & 1.812 & 1 & 64 & 0.183 \\
\hline
\end{tabular}

Table 15 shows that both data came from homogeneous data because the significant value was more than 0.05. Because of the analysis prerequisites are qualified, a t-test is performed.

Table 16. Paired Sample Test

\begin{tabular}{|c|c|c|}
\hline \multicolumn{3}{|c|}{ Paired Sample Test } \\
\hline \multirow{2}{*}{\multicolumn{2}{|c|}{ ABC19 - AAC19 }} & ig. (2-tailed) \\
\hline & & 0.508 \\
\hline \multirow{2}{*}{\multicolumn{3}{|c|}{$\begin{array}{l}\text { The significant value in table } 16 \text { is } 0.508 \text {. When the significant value is less than } 0.05 \text {, the decisio } \\
\text { the data has a significant difference, vice versa. It shows that there is no significant difference between the us } \\
\text { assessment instruments in physics learning before and during the Covid-19 } \\
\text { Table 17. The Frequency Distribution of Teachers' Interest in The Development and Availability of The } \\
\text { EFA in ElboW }\end{array}$}} \\
\hline & & \\
\hline \multicolumn{2}{|r|}{ Interested on Development } & Interested on Availability \\
\hline Not at all Interested & 0 & 0 \\
\hline Not Very Interested & 1 & 1 \\
\hline Interested & 19 & 19 \\
\hline Very Interested & 13 & 13 \\
\hline Total & 33 & 33 \\
\hline
\end{tabular}

Table 17 shows that 13 teachers are very interested in the development and availability of EFA in ElboW, 19 teachers are interested in the development and availability of EFA in ElboW, 1 teacher is less 
interested in the development and availability of EFA in ElboW, and there are no teachers who are not very interested in the development and availability of EFA in ElboW.

Table 18. The Frequency Distribution of Teachers' Agreement about Facilities in The EFA in ElboW

\begin{tabular}{ccccc}
\hline & \multicolumn{4}{c}{ Teachers' Agreement } \\
\cline { 2 - 5 } & Strongly Disagree & Disagree & Agree & Strongly Agree \\
\hline Video & 0 & 0 & 14 & 19 \\
Teaching Material & 0 & 0 & 13 & 20 \\
Discussion & 0 & 1 & 18 & 14 \\
Virtual Experiment & 0 & 1 & 18 & 14 \\
\hline
\end{tabular}

19 out of 33 teachers strongly agree, 14 out of 33 teachers agree if there are videos in e-learning, and there are no teachers who strongly disagree or disagree if the video becomes a facility in e-learning. 20 out of 33 teachers strongly agree, 13 out of 33 teachers agree if there are teaching materials in elearning, and there are no teachers who strongly disagree or disagree if teaching materials become facility in e-learning. 14 of 33 teachers strongly agree if there is a discussion facility in e-learning, 18 of 33 teachers agree if there is a discussion facility in e-learning, 1 of 33 teachers disagree if there are discussion facilities in e-learning, and there are no teachers who do not agree if there is a discussion facility. 14 of 33 teachers strongly agree if there is a virtual experiment facility in e-learning, 18 of 33 teachers agree if there is a virtual experiment facility in e-learning, 1 of 33 teachers disagree if there is virtual experiment facility in e-learning, and there are no teachers who do not agree if there is virtual experiment facility.

\section{Discussion}

This section will discuss the findings of the research. The first is a significant change in the aspect of assessing. This journal (Hatip, 2020) also reveals that the assessment is something that is affected. The journal also reveals that assessment for learning is a suitable assessment approach for distance learning. During the COVID-19 Pandemic, the government took a policy to close school institutions and implement distance learning to reduce the spread of the Severe Acute Respiratory Syndrome coronavirus 2 (SARSCoV-2) Virus. This kind of distance learning results in the implementation of the assessment not like usual. The COVID-19 pandemic has resulted in fewer teachers assessing at the beginning and end of physics lessons because assessing at the beginning and the end of the learning process requires a long time, starting from preparing, implementing, collecting, and giving the result of the assessment. Therefore, the teacher, of course, will consider the learning time and choose to deliver the learning material. There are fewer types of instruments used by the teacher to make assessments both at the beginning and the end of the lesson. The use of variations in instruments before the pandemic was more than during the COVID-19 pandemic because of the COVID-19 pandemic that does not support teachers to use various types of instruments. For example, effective assessment instruments are easier to use before the COVID-19 pandemic than during the COVID-19 pandemic because teachers and students can meet face-to-face (Rigianti, 2020). In other words, the current situation that requires learning with a distance learning system does not provide a great opportunity for teachers to use various types of research instruments, and it turns out that the type of assessment instrument most commonly used before and during the COVID-19 pandemic by teachers is the essay test. and multiple-choice tests because they have many advantages likely: open-minded, not easy to cheat, can find students' problems in solving questions, and give a more accurate evaluation for the students (Aalaei, Ahmadi, \& Aalaei, 2016) (Tozoglu, Tozoglu, Gurses, \& Dogar, 2004). Although both instruments type is most often used, the number of teachers using them has decreased due to the COVID-19 pandemic. the number of teachers who give assignments and feedback is also getting less. It is caused by the COVID-19 pandemic situation which causes teachers to have difficulty in giving and correcting assignments. So that teachers do not provide feedback to student assignments and do not inform students. Likewise, the frequency of teachers who provide feedback to the test results was getting smaller because of the less time so the teacher prioritized delivering learning material. In a lesson, giving feedback is the crucial thing. That is because by providing feedback to students about the strengths and weaknesses of the students, the teachers can change students' perspectives about their abilities and intrinsic motivation (Badami, Vaezmousavi, Wulf, \& Namazizadeh, 2011). Due to its urgency in learning, providing feedback must be considered even if it is in a distance learning system.

The teaching aspect is an aspect that has also undergone significant changes due to the COVID-19 pandemic. Where the frequency of teachers who have done online learning is increasing. The teachers use various online learning service providers, namely Google Classroom, Whatsapp Group, Google Meet, Zoom, 
and Other providers to conduct online learning. Using score, Google Classroom. In this research, WhatsApp is the most used application because it has some advantages. The advantages of Whastapp; Facilitator's availability, learning anytime-anywhere, easy to use, downloadable, easily available, low cost, provides privacy and online cooperation and collaboration (Gon \& Rawekar, 2017) (Barhoumi, 2015) (Amry, 2014). As more and more teachers are learning online, it turns out that the pandemic has also resulted in more teachers not using the discussion method. Teaching by discussion in the learning process helps students think critically about the topic taught by the teacher (Rahman, et al., 2011). Then, this pandemic also caused fewer teachers to carry out practicum in learning.

The aspect of using validated assessment instruments was not significantly affected in other words, there was only a small increase in the frequency of teachers using validated assessment instruments. This happens because there is no increase in the ability of teachers in making validated instruments. This is supported by research in the article (Aji \& Winarno, 2016), which found that $75 \%$ of the questions used by the teacher were invalid. This finding aroused the researchers' curiosity to interview the teacher. As a result, the teacher's lack of understanding in preparing a validated instrument so that the teacher only made the instrument without thinking about whether the instrument was validated or not. Even though it is still in the condition of the COVID-19 pandemic, it is necessary to increase the skills of teachers in making valid assessment instruments. The way to increase teacher skills in making validated assessment instruments can be done by persuading teachers to attend online seminars on making validated assessment instruments.

\section{Conclusion}

The Integration of E-Formative Assessment in E-Learning based on Website (EFA in ELboW) is a learning medium needed during a pandemic by physics teachers and other subject teachers. This media can help physics teachers and teachers of other subjects in facing the challenges that arise as a result of the significant impact of teaching and assessing aspects. Also, this media is facilitated with facilities based on literature reviews and teacher needs so that the produced media by involving teachers as education practitioners will suit the needs in the field. This media is not only beneficial for teachers but also the student because this media integrates elements of e-learning and formative assessment so that it can provide benefits to students so that student learning motivation increases. For physics teachers, this research result informs there are effects due to the COVID-19 in the physic learning process, namely 2 of the three aspects of learning studied by researchers experienced significant changes due to the existence of COVID-19.

\section{References}

Aalaei, S., Ahmadi, M. A., \& Aalaei, A. (2016). A Comparison of Multiple-Choice and Essay Questions In The Evaluation of Dental Students. International Journal of Advandced Biotechnology and Research, 7(5), 1674-1680. http://eprints.qums.ac.ir/5868/1/ijabr201605210Shima.pdf.

Aji, B. S., \& Winarno, M. E. (2016). Pengembangan Instrumen Penilaian Pengetahuan Mata Pelajaran Pendidikan Jasmani Olahraga dan Kesehatan (PJOK) Kelas VIII Semester Gasal. Jurnal Pendidikan: Teori, Penelitian, dan Pengembangan, 1(7), 1449-1463. http://dx.doi.org/10.17977/jp.v1i7.6594.

Akani, O. (2015). Laboratory Teaching: Implication on Students' Achievement In Chemistry in Secondary School In Ebonyi State of Nigeria. Journal of Education and Practice, 6(30), 206-213. https://eric.ed.gov/?id=EJ1081346.

Alfian, A., Aminah, N. S., \& Sarwanto, S. (2015). Authentic Assessment Berbasi Scientific Approach sebagai Implementasi Kurikulum 2013 di SMP Kelas VII pada Materi Suhu dan Perubahannya. Jurnal Inkuiri, 4(3), 39-50. https://jurnal.fkip.uns.ac.id/index.php/inkuiri/article/view/7814.

Alneyadi, S. S. (2019). Virtual Lab Implementation in Science Literacy: Emirati Science Teachers' Perspectives. Eurasia Journal of Mathematics, Science and Technology Education, 15(12), 1-10. https://doi.org/10.29333/ejmste/109285.

Ambusaidi, A., Musawi, A. A., Al-Balushi, S., \& Al-Balushi, K. (2018). The Impact of Virtual Lab Learning Experiences on 9th Grade Students' Achievement and Their Attitudes Towards Science and Learning by Virtual Lab. Journal of Turkish Science Education, 15(2), 13-29. http://www.tused.org/index.php/tused/article/view/207. 
Amry, A. B. (2014). The Impact of Whatsapp Mobile Social Learning on The Achievement and Attitudes of Female Students Compared with Face to Face Learnin. European Scientific Journal, 10(22), 116136. https://core.ac.uk/download/pdf/328024433.pdf.

Asıksoy, G., \& Islek, D. (2017). The Impact of the Virtual Laboratory on Students' Attitude in a General Physics Laboratory. International Journal of Online and Biomedical Engineering, 13(4), 20-28. https://core.ac.uk/download/pdf/270196739.pdf.

Badami, R., Vaezmousavi, M., Wulf, G., \& Namazizadeh, M. (2011). Feedback After Good Versus Poor Trials Affects Intrinsic. Physical Education, Recreation and Dance, 82(2), 360-364. https://doi.org/ 10.1080/02701367.2011.10599765.

Baird, J.-A., Andrich, D., Hopfenbeck, T. N., \& Stobart, G. (2017). Assessment and Learning: Fields apart? Assessment in Education: Principles, Policy \& Practice, 24(3), 317-350. https://doi.org/10.1080/0969594X.2017.1319337.

Barhoumi, C. (2015). The Effectiveness of WhatsApp Mobile Learning Activities Guided by Activity Theory on Students Knowledge Management. Contemporary Educational Technology, 6(3), 221-238. https://eric.ed.gov/?id=EJ1105764.

Cullin, M., Hailu, G., Kupilik, M., \& Petersen, T. (2017). The Effect of an Open-Ended Design Experience on Student Achievement in an Engineering Laboratory Course. International Journal of Engineering Pedagogy, 7(4), 102-116. https://www.learntechlib.org/p/207426/.

Dewa, E., Mukin, M. U., \& Pandango, O. (2020). Pengaruh Pembelajaran Daring Berbantuan Laboratorium Virtual terhadap Minat dan Hasil Belajar Kognitif Fisika. Jurnal Riset Teknologi dan Inovasi Pendidikan, 3(2), 351-359. http://journal-litbangrekarta.co.id/index.php/jartika/article/view/288.

El-Seoud, M. S., Taj-Eddin, I. A., Seddiek, N., El-Khouly, M. M., \& Nosseir, A. (2014). E-Learning and Students' Motivation: A Research Study on the Effect of E-Learning on Higher Education. International Journal of Emerging Technologies in Learning, 9(4), 20-26. http://www.aun.edu.eg/reserches_files/25615.pdf.

Gon, S., \& Rawekar, A. (2017). Effectivity of E-Learning trough Whatsapp as a Teaching Learning Tool. MVP $\begin{array}{llll}\text { Journal of } & \text { Medical }\end{array}$ http://dx.doi.org/10.18311/mvpjms\%2F0\%2Fv0\%2Fi0\%2F8454.

Hatip, A. (2020). The Transformation of Learning During Covid-19 Pandemic Towards the New Normal Era. International Webinar on Education 2020, (pp. 18-28). http://journal.umsurabaya.ac.id/index.php/Pro/article/view/5947.

Isnaepi, I., \& Suparman, S. (2018). Analisis Kebutuhan Pengembangan E-Learning untuk mengembangkan Kemampuan Memecahkan Masalah Siswa kelas XII SMA. Seminar Nasional Pendidikan Matematika Ahmad Dalan, 63-99. http://seminar.uad.ac.id/index.php/sendikmad/article/view/475.

Jadhav, V. R., Bagul, T. D., \& Aswale, S. R. (2020). CoVID-19 Era: Students' Role to Look at Problem in Education System during Lockdown Issues in Maharashtra, India. International Journal of Research and Review, 7(5), 328-331. https://www.academia.edu/download/63595085/IJRR004920200611-111871-y7pzs9.pdf.

Jingga, A. A., Mardiyana, M., \& Triyanto, T. (2018). Pendekatan dan Penilaian Pembelajaran pada Kurikulum 2013 Revisi 2017 yang mendukung Peningkatan Kemampuan Koneksi Matematis Siswa. Jurnal Elektronik Pembelajaran Matematika, 5(3), 286-299. https://jurnal.uns.ac.id/jpm/article/view/26076.

Karim, S. A., \& Lamada, M. S. (2016). Analisis Kebutuhan Pembelajaran Berbasis E-Learning dengan Modular Object-Oriented Dynamic Learning Environment di SMK Negeri 3 Parepare. Jurnal Mekom, 3(1), 46-52. https://doi.org/10.26858/mekom.v3i1.2616.

Li, Q., Guan, X., Wu, P., Wang, X., Zhou, L., Tong, Y., Feng, Z. (2020). Early Transmission Dynamic in Wuhan, China, of Novel Coronavirus-Infected Pneumonia. The New England Journal of Medicine, 1(1), 1-9. https://doi.org/10.1056/NEJMoa2001316. 
Mustakim. (2020). Efektivitas Pembelajaran Daring menggunakan Media Online Selama Pandemi CoVID19 pada Mata Pelajaran Matematika. Al asma : Journal of Islamic Education, 2(1), 1-12. https://doi.org/10.24252/asma.v2i1.13646.

Prem, K., Liu, Y., Russell, T. W., Kucharski, A. J., Eggo, R. M., \& Davies, N. (2020). The Effect of Control Strategies to Reduce Social Mixing on Outcomes of the COVID-19 epidemic in Wuhan, China : a modelling study. Lancet Public Health, 5(5), 1-10. https://doi.org/10.1016/S24682667(20)30073-6..

Putria, H., Maula, L. H., \& Uswatun, D. A. (2020). Analisis Proses Pembelajaran Dalam Jaringan (DARING) Masa Pandemi COVID-19 pada Guru Sekolah Dasar. Jurnal Basicedu, 4(4), 961-872. https://doi.org/10.31004/basicedu.v4i4.460.

Rahman, F., Khalil, J. K., Jumani, N. B., Ajmal, M., Malik, S., \& Sharif, M. (2011). Impact of Discussion Method on Students Performance. International Journal of Business and Social Science, 2(7), 84-94. https://citeseerx.ist.psu.edu/viewdoc/download?doi=10.1.1.455.2621\&rep=rep1\&type=pdf.

Rigianti, H. A. (2020). Kendala Pembelajaran Daring Guru Sekolah Dasar di Kabupaten Banjarnegara. Elementary School, 7(2), 297-302. https://doi.org/10.31316/esjurnal.v7i2.768.

Rusyan, T., Kusdinar, A., \& Arifin, Z. (1989). Pendekatan dalam Proses Belajar Mengajar. Remadja Karya.

Sadeghi, M. (2019). A shift from Classroom to Distance Learning: Advantages and Limitations. International Journal of Research in English Education, 4(1), 80-88. http://ijreeonline.com/browse.php?a_id=132\&sid=1\&slc_lang=fa.

Sandybayev, A. (2020). The Impact of E-Learning Technologies on Student's Motivation: Student Centered Interaction in Business Education. International Journal of Research in Tourism and Hospitality, 6(1), 16-24.

Susilawati, S., Falefi, R., \& Purwoko, A. (2020). Impact of COVID-19's Pandemic on the Economy of Indonesia. Budapest International Research and Critics Institute-Journal, 3(2), 11475-1156. https://doi.org/10.33258/birci.v3i2.954.g1284.

Taherdoost, H. (2016). Sampling Methods in Research Methodology; How to Choose a Sampling Technique for Research. International Journal of Academic Research in Management, 5(2), 18-27. https://papers.ssrn.com/sol3/papers.cfm?abstract_id=3205035.

Tozoglu, D., Tozoglu, M. D., Gurses, A., \& Dogar, C. (2004). The students' perceptions: Essay Versus Multiple-choice Type Exams. Journal of Baltic Science Education, 2(6), 52-59.

Upoalkpajor, J. L., \& Upoalkpajor, C. B. (2020). The Impact of COVID-19 on Education in Ghana. Asian Journal of Education and Social Studies, 9(1), 23-33. https://doi.org/10.9734/ajess/2020/v9i130238.

Wargadinata, W., Maimunah, I., Dewi, E., \& Rofiq, Z. (2020). Student's Responses on Learning in the Early COVID-19 Pandemic. Tadris : Journal of Education and Teacher Training, 5(1), 141-153. http://ejournal.radenintan.ac.id/index.php/tadris/article/view/6153.

Wong, S. S., Firestone, J. B., Luft, J. A., \& Weeks, C. B. (2013). Laboratory Practices of Beginning Secondary Science Teachers: A Five-Year Study. Science Educator, 22(1), 1-9. https://eric.ed.gov/?id=EJ1062174.

Yuliana, Y. (2020). Corona Virus diseases (Covid-19); Sebuah Tinjauan Literature. Wellness ad Healthy Magazine, 2(1), 187-192. https://doi.org/10.30604/well.95212020.

Zheng, J. (2020). SARS-CoV-2: An Emerging Coronavirus that Cause a Global Threat. International Jurnal of Biological Science,
https://www.ncbi.nlm.nih.gov/pmc/articles/PMC7098030/.

1678-1685. 